\title{
When the Office of Health Standards Compliance inspector knocks: What do I do?
}

\author{
H J van As, BIuris, LLB, LLD, NDip(Pol) \\ Department of Public Law, Faculty of Law, Nelson Mandela University, Port Elizabeth, South Africa
}

Corresponding author: HJ van As (hennie.vanas@mandela.ac.za)

\begin{abstract}
Inspectors and health officers attached to the Office of Health Standards Compliance (OHSC) may inspect or investigate premises where health services are provided, and may then perform a number of actions, including questioning people, taking samples, requesting documents, and conducting inspections and investigations. The outcomes of these activities may result in a number of sanctions, some of which may seriously impact health establishments and practitioners. This article aims to review the rights that health establishments, healthcare providers and health workers have when subjected to inspections or investigations by the OHSC. It also recommends a number of steps that may be taken when an inspector arrives at an establishment.
\end{abstract}

S Afr Med J 2018;108(11):922-925. DOI:10.7196/SAMJ.2018.v108i11.13205

The Office of Health Standards Compliance (OHSC) was established by section 77 of the National Health Act ${ }^{[1]}$ (hereafter referred to as 'the Act') and, from an enforcement perspective, it has three main responsibilities: to monitor, inspect and investigate. As a measure to protect the citizenry, the promulgation of the Act should be welcomed. However, practitioners and healthcare establishments should be aware of their rights, or risk becoming victims of inexperienced and overzealous inspectors. ${ }^{[2]}$

While it is generally accepted that there is a difference between public and private healthcare in South Africa (SA), ${ }^{[3]}$ and it is understandable that all inspections undertaken by the OHSC in 2015/2016 (3) ${ }^{[4]}$ were conducted at public establishments, while those at private establishments will be introduced - at higher inspection ratios. The indicators and annual targets are evidence of this and are set out in Table $1(2015 / 2016(10)){ }^{[4]}$

Taking into account that there are 3816 public as opposed to 369 private establishments, it means that the already stretched administrative and management resources at these establishments, especially at private institutions because of the high inspection ratios and at public institutions because of chronic under-resourcing, could become strained, according to the OHSC in 2015/2016 (7)..$^{[4]}$ Complying with requests from inspectors for documents, records, objects and materials will be time- and labour-consuming exercises.

This article aims to review the rights that health establishments, healthcare providers and health workers have when subjected to inspections or investigations by health officers and inspectors of the OHSC. Section $81 \mathrm{~A}$ of the Act ${ }^{[1]}$ also established the office of the ombud, which mainly deals with complaints related to norms and standards, but this article focuses on the functions and powers of health officers and inspectors. It is important to know these rights, as section 1 of the Constitution ${ }^{[5]}$ establishes SA as a constitutional democracy based on core values, including the advancement of human rights and freedoms. The state, represented here by health officers, inspectors and the ombud, must respect, promote and fulfil the rights contained in section 7(2) of the Constitution, ${ }^{[5]}$ but a knowledgeable citizenry can better protect itself against possible abuse. Failure to respect or insist on respect for these rights may have dire consequences for healthcare establishments and practitioners, including the issuing of notices of compliance to persons in charge, warnings that establishments might be closed, imposition of fines and referring matters to the National Prosecution Authority for criminal prosecution in terms of section 82 of the Act. ${ }^{[1]}$

\section{The legislative regimen}

In terms of section 78 of the Act, ${ }^{[1]}$ the objects of the OHSC are to protect and promote the health and safety of users of health services by: - monitoring and enforcing compliance with norms and standards

- investigating and disposing of complaints relating to noncompliance with the norms and standards. ${ }^{[6]}$

In terms of section 79(1) of the Act, ${ }^{[1]}$ a core business (only the subsections relevant to this discussion are listed) of the OHSC is to:

- inspect and certify health establishments as compliant or noncompliant with prescribed norms and standards or, where appropriate and necessary, withdraw such certification

- investigate complaints relating to breaches of prescribed norms and standards

- monitor indicators of risk as an early-warning system relating to serious breaches of norms and standards and report breaches.

Table 1. Indicators and annual targets for inspections

\begin{tabular}{|c|c|c|c|}
\hline \multirow[b]{2}{*}{ Programme performance indicator } & \multirow[b]{2}{*}{ Strategic plan target, $\%$} & \multicolumn{2}{|c|}{ Medium-term targets, $\%$} \\
\hline & & $2017 / 2018$ & $2018 / 2019$ \\
\hline $\begin{array}{l}\text { Public health establishments } \\
\text { inspected annually }\end{array}$ & 20 & 17 & 18 \\
\hline Private-sector health establishments inspected annually & 30 & 25 & 30 \\
\hline
\end{tabular}


Section 80(1) of the $\mathrm{Act}^{[1]}$ provides for the appointment of health officers and inspectors to monitor, inspect and investigate. In terms of section 82 a health officer may enter and inspect any premises, excluding a private dwelling, whereas an inspector may enter and inspect any health establishment at any reasonable time. In accordance with sections 80(4)(a) and (b), they must be issued with an appointment certificate, be in possession of it when performing any official function, and must show it to any person who is affected by their actions. Section 80(4)(c) bestows on health officers and inspectors (hereafter referred to as 'inspector') the powers of peace officers as defined in section 1 of the Criminal Procedures Act. ${ }^{[7]}$

Section 84 of the Act ${ }^{[1]}$ allows for an inspector to be accompanied by a police official and, on the authority of a warrant issued by a magistrate or a judge, to enter any premises, including a private dwelling or health establishment specified in the warrant, and:

- inspect, photograph, copy, test and examine any document, record, object or material

- seize any document, record, object or material if he or she has reason to suspect that it might be used in evidence in a criminal trial

- examine any activity, operation or process carried out on the premises or health establishment.

The warrant may impose restrictions on the powers of the health officer or inspector and it must be executed by day, unless the person who issues the warrant authorises the execution thereof by night. An inspector who removes anything from the premises or health establishment must issue a receipt for the item.

On request of an inspector acting in terms of a warrant, the occupant and any other person present on the premises or health establishment must make available or accessible or deliver to the inspector any document, record, object or material which pertains to an investigation or inspection. Such persons must also furnish information pertaining to the matter under investigation or inspection and render reasonable assistance. However, section 84(4) of the $\mathrm{Act}^{[1]}$ states that, before questioning any person, an inspector must advise that person of his or her right to be assisted at the time by an advocate or attorney, and be allowed to exercise that right.

In terms of section 81(a)(1)-(5) of the Act, ${ }^{[1]}$ the Minister may also appoint an ombud who may investigate and dispose of complaints relating to norms and standards. During an investigation, the ombud may obtain an affidavit or a declaration from any person; direct any person to appear, to give evidence or to produce any document in his or her possession or under his or her control that has bearing on the matter under consideration or being investigated; and interrogate such person. The ombud may also require any person by way of a subpoena to appear as a witness to give evidence. When the ombud calls, it is an investigation and not an inspection, giving rise to the right to privacy and the rights afforded to suspects.

\section{The issues and the Constitution}

Firstly, section 14 of the Constitution ${ }^{[5]}$ grants everyone the right to privacy, which includes the right not to have their person, home or property searched. This right is infringed upon when inspections or investigations are undertaken in a manner inconsistent with the Constitution or any enabling legislation, such as the Act. ${ }^{[1]}$ The manner in which the courts have interpreted this right is examined below.

Secondly, although section 35 of the Constitution deals with the rights of arrested, detained and accused persons, the courts found that suspects enjoy the same rights. ${ }^{[8]}$ According to the court '... it stands to reason that a person must be informed that he/she is a suspect, in order that he/she can properly consider and exercise his/ her rights before interacting with ...' law enforcement agencies. These include the right:

- to remain silent

- to be informed promptly of the right to remain silent and of the consequences of not remaining silent

- not to be compelled to make any confession or admission that could be used in evidence against that person (this would include an entity represented by a person)

- to choose, and to consult with a legal practitioner, and to be informed of this right promptly.

When a person or health establishment is a suspect, certain rights accrue. To protect these rights, it must be established who the focus of the inspection is and whether they became a suspect during the inspection. Section 35 of the Constitution ${ }^{[5]}$ determines that evidence obtained in a manner violating any right in the Bill of Rights 'must be excluded if the admission of that evidence would render the trial unfair or otherwise be detrimental to the administration of justice. There will, however, be times 'when fairness will require that evidence, albeit obtained unconstitutionally, nevertheless be admitted. ${ }^{[9]}$

The rights contained in the Bill of Rights are not absolute - in terms of section 36(1)(e), it may be limited by a law of general application, as long as the limitation is reasonable and justifiable in an open and democratic society based on human dignity, equality and freedom. An example of such a generally applicable law is the Act ${ }^{[1]}$ that limits the right to privacy by granting inspectors the power to inspect, provided that such limitation complies with section 36 of the Constitution ${ }^{[5]}$ and the provisions of the Act itself.

\section{Inspection $\mathrm{v}$. investigation}

Depending on whether an inspection is undertaken or whether a matter is investigated, different rules of law apply; ${ }^{[10]}$ therefore, it is important to distinguish between inspections and investigations.

The primary purpose of an inspection is to verify whether there is compliance with legislation, including norms and standards. Where inspections are undertaken, the officer does so as a matter of routine and not in the belief that the law was violated. By applying for a certificate of need in accordance with section 36 of the Act, ${ }^{[1]}$ the recipient of the certificate by implication allows inspections to take place, thus granting tacit permission for an invasion of privacy. The fact that a certificate may be withdrawn, also implies the right of the OHSC to inspect, as it is impossible to establish levels of compliance without conducting inspections.

The purpose of an investigation is to gather information and evidence to support the prosecution of a suspected violation of the law where there are reasonable grounds to believe that an offence has been committed. In terms of section 18(1) of the Act, ${ }^{[1]}$ investigations could have their origin in complaints laid by persons who feel aggrieved by the manner in which they were treated by health establishments; or where there is non-compliance with the norms and standards prescribed by section 78(1)(b); or during an inspection conducted in terms of section 79 , something could have been discovered that provides reasonable grounds to suspect that an offence might have been committed. The inspector must then indicate this as such, and normally a search warrant is required unless there are urgent circumstances. ${ }^{[1]}$

In the exercise of powers, inspectors frequently conduct routine inspections and gather evidence, which may subsequently become relevant for use in prosecution - should the matter move from an 
inspection to an investigation. This is not a challenge - if the official lawfully entered during a routine inspection and found evidence of non-compliance, the inspection simply becomes a search and all evidence then gathered remains admissible. However, where an official has a reasonable suspicion of non-compliance from the outset, and fails to obtain a search warrant subject to a few exceptions, the entry will be unlawful and the evidence is likely to be inadmissible.

An inspection may be announced or unannounced (routine compliance inspections) - no prior authorisation is required, or it may be in response to a complaint. Investigations may have their origin in complaints, but also from the discovery during a compliance inspection warranting further investigation. As far as the latter instance is concerned, the critical question is: At what point does that inspection become an investigation? The inspector decides at which point it must be indicated that the inspection has given rise to a reasonable suspicion that an investigation is required. An investigation implies that suspicious activities are or have been taking place and that there is a 'suspect' who has rights protected by the Bill of Rights. Section 35 of the Constitution ${ }^{[5]}$ states that arrested, detained or accused persons have rights and have the right to be informed thereof, but the courts have interpreted this to include suspects. ${ }^{[12]}$ Therefore, failure to inform suspects of their rights has certain consequences, including whether documents, statements and any other evidence may be used in criminal proceedings or whether such evidence will be excluded.

\section{What do the courts say?}

In Estate Agency Affairs Board v Auction Alliance, ${ }^{[12]}$ section 32A of the Estate Agency Affairs $\mathrm{Act}^{[13]}$ that conferred wide powers of inspection, search and seizure on regulatory bodies was declared constitutionally invalid. According to the court, a routine inspection can take place without a warrant, where the legislation allows for it, but if there is a suspicion that an offence has been committed, a warrant must be obtained, except where a delay frustrates the objectives of the search, or where a person with the power to do so grants permission for a search without a warrant. The court ruled that warrantless routine inspections generally meet constitutional muster and are consequently valid. Statutory provisions that provide for targeted 'inspections' (where there is already suspicion of wrongdoing) without a warrant are, however, unconstitutional and invalid.

The case of Magajane $v$ Chairperson, North West Gambling Board $^{[14]}$ questioned whether legislation may authorise warrantless inspections of premises for the purpose of obtaining evidence for criminal prosecutions and whether this would be consistent with the constitutional right to privacy (para 1). ${ }^{[14]}$ Certain provisions of the North West Gambling Act ${ }^{[15]}$ were challenged on the grounds that they violated the right to privacy by authorising inspectors to search commercial premises and seize items without a warrant. The court held that a right of a regulated business to privacy was diminished the more its business was public, closely regulated and potentially hazardous to the public (para 50). ${ }^{[14]}$ It emphasised the importance of the right to privacy and that the purpose of the limitation (granting the right to inspect) was to protect public confidence and trust in individuals and institutions involved in the industry. However, as the authorisation provided no guidelines as to how the searches were conducted, the limitation was not justifiable, and inspections should be done with warrants.

Mistry $v$ Interim National Medical and Dental Council of South Africa ${ }^{[16]}$ dealt with the search of a registered medical practitioner's surgery in terms of section 28(1) of the Medicines and Related Substance Control Act. ${ }^{[17]}$ The court held that the purpose of the search and seizure was the general welfare of the community, but that the extent of the invasion of privacy was disproportionate to that purpose: it was too broad, as no warrant was required and it authorised unrestricted entry and search. There was a lack of qualification (setting of limits) of inspectors' powers of entry and inspection within this Act. Generally, it stated that these powers must be exercised at reasonable times and conducted with regard to the right to dignity and privacy. However, once on the premises, an inspector could examine, photograph or take samples of almost anything, whether acting on the strength of a warrant or not. Section 28(1) did not 'require a warrant to be issued in any circumstances at all. ${ }^{[16]}$

The courts have clarified the importance, during inspections, of gaining assurance from an inspector (verbally or in writing) that he or she is not conducting a criminal investigation, alternatively confirming that any information or documentation sought is solely for the purpose of a compliance inspection. Should there be any question regarding the inspector's intentions, the subject of an inspection is able to insist on exercising his or her rights as set out in the Constitution. ${ }^{[5]}$ Sections 10, 12(1)(e), 19, 25, 32 and 35 protect the rights to dignity, not to be treated in a degrading way, privacy, property rights, access to information and just administrative action respectively. In the event that health establishments, healthcare providers and health workers become suspects, they will also enjoy the rights afforded to arrested, detained and accused persons by section 35 of the Constitution. ${ }^{[5]}$

\section{Inspection or investigation?}

When an inspection turns into an investigation, the constitutional rights afforded to suspects (as interpreted by the courts) must be respected. Failure to do so may impact on the admissibility of evidence in enforcement proceedings. To determine whether a routine inspection has led to a suspicion that an investigation is required, it is important to bear in mind the following factors:

- Did the authorities take a decision to undertake a criminal investigation from the start or was an inspection conducted initially with the purpose to gather further evidence?

- What was the origin of the decision? Where a complaint was received or information provided that triggered the action, the conduct that followed should be considered an investigation and not an inspection.

- Was the general conduct of the authorities consistent with that of a criminal investigation?

- If there was an initial inspection, did the inspector transfer his or her files and materials to investigators?

- Could the inspector be perceived to be gathering evidence for investigators?

- Are there any other circumstances or factors that can lead to the conclusion that the compliance inspection had become a criminal investigation?

\section{Recommendations}

When an inspector arrives at an establishment or premises, health establishments, healthcare providers and health workers should take the following steps:

- Before permission to enter is given, establish the identity of the inspector (ask for an appointment certificate) and determine whether he or she has the authority to conduct an inspection or investigation.

- Ask the reason for the visit and specifically ask whether it is a routine inspection or not.

- If requested to grant consent that an inspection may be conducted, 
be sure that the person who can does grant such consent. Permission to grant consent should be in writing and it does not always have to be the same person.

- If you are not the person in charge, explain that you do not have the authority to grant consent, and notify the person in charge.

- If you are the person in charge, you have the right to request the presence of an attorney or advocate.

- If it is indicated that it is not a routine inspection, ask to see the warrant. You have the right not to say anything and to be informed of this right by the person conducting the inspection.

- If an inspection is conducted at night with a warrant, establish whether the warrant is valid for execution at night.

\section{Conclusion}

The Act ${ }^{[1]}$ was promulgated for the public good, and the threat of legal consequences should not determine attitudes towards it. ${ }^{[18]}$ The interests of the subject of an inspection or investigation are protected by knowing one's rights and insisting that they are respected. These rights may be waived by choosing not to exercise them, or choosing to exercise them only in a certain way, but for such an undertaking to be binding, the waiver must be voluntary and the subject must be informed of the consequences of such a waiver. ${ }^{[19]}$ Consent can only be properly given if the giver thereof knows his or her rights and what the effect of such consent is.

\section{Declaration. None}

Acknowledgements. None.

Author contributions. Sole author, with input by Adv. Phil Snijman,
Research Associate, Department of Public Law, Faculty of Law, Nelson Mandela University, Port Elizabeth, SA.

Funding. None.

Conflicts of interest. None.

1. South Africa. National Health Act No. 61 of 2003

2. Whittaker S, Shaw C, Spieker N, et al. Quality standards for healthcare establishments in South Africa. S Afr Health Rev 2011;64(5):59-67.

3. Patel AD. A world of difference between private and public healthcare in South Africa. The Daily Vox, 28 March 2017. https://www.thedailyvox.co.za/a-world-of-difference-between-private-and-publichealthcare-in-south-africa/ (accessed 4 January 2018)

4. National Department of Health. Office of Health Standards Compliance, Annual Inspection Report 2015/2016. 2016. https://www.gov.za//sites/default/files/dohannual\%20report\%20\%202016\%20reduced_a. pdf (accessed 30 May 2018).

5. South Africa. Constitution of the Republic of South Africa 1996

6. National Department of Health, South Africa. Norms and standards regulations applicable to different categories of health establishments. Government Gazette No. 40539:10. 2017.

7. South Africa. Criminal Procedures Act No. 51 of 1977.

8. S v Orrie and Another [2004] ZWCHC 25.

9. Key v Attorney General, Cape Provincial Division (supra) at $196 \mathrm{~A}-\mathrm{C}$ and quoted in S v Orrie and Another 2004 ZWCHC 25.

10. Halladay CW. Regulatory investigations: Best practices inspections/audits $\mathrm{v}$ investigations. 2011. https://www.google.co.za/?gfe_rd=cr\&ei=qOYMV7-ZBeao8wezz7qoCQ\&gws_rd=ssl I $q=r+v+j a r v i s$ https://www.google.co.za/?gfe_rd=cr\&ei=qOYMV7-ZBeao8wezz7qoCQ\&gws_rd=ssl (accessed 19 December 2017).

11. Nova Scotia Federation of Agriculture. Educational Resources: Nova Scotia. Undated. http://nsfafane. ca/educational-resources/environmental-law-qa/enforcement-inspection-investigations/ (accessed 11 April 2016).

12. Estate Agency Affairs Board v Auction Alliance 2014 (3) SA 106 (CC)

13. South Africa. Estate Agency Affairs Act No. 112 of 1976.

14. Magajane v Chairperson, North West Gambling Board 2006 (5) SA 250 (CC).

5. South Africa. North West Gambling Act No. 2 of 2001

16. Mistry v Interim Medical and Dental Council of South Africa and Others 1998 (4) SA 1127 (CC).

17. South Africa. Medicines and Related Substances Control Act No. 101 of 1965.

18. Buys M. Protecting personal information: Implications of the protection of personal information (POPI) Act for healthcare professionals. S Afr Med J 2017;107(11):954-956. https://doi.org/10.7196/ SAMJ.2017.v107i11.12542

19. Rautenbach IM. Constitutional Law. Durban: Lexis Nexis, 2012 